\title{
Motivation to Learn English When Facing Difficulties and Fatigue Among ESL Students of University of Arkansas
}

Erizar

STAIN Teungku Dirundeng Meulaboh, Aceh, Indonesia

Correspondence: Erizar, Indonesia. e-mail: eri_zar@yahoo.com

Received: July 12, 2019

Accepted: Augustus 09, 2019

Online Published: October 1, 2019

DOI: $10.29408 /$ veles.v3i2.1482.g921

URL: http://dx.doi.org/ 10.29408/veles.v3i2.1482.g921

\begin{abstract}
This study aims to explore motivation to learn English when facing difficulties and fatigue among ESL students of University of Arkansas based on the level of their study ,gender, age, living status (living alone and living with others). To collect the data, graduate and undergraduate degree holders were asked to take the survey voluntarily. The result of research indicates that there is no significant different between undergraduate holder (mean $=3.54$; std.dev $=0.48)$ and graduate degree holders $($ mean $=3.64 ;$ std.dev $=0.52$, based on independent $t$-test, $t=-1.270$, p-value $>0.05$ ) However, when comparing the motivation based on the gender, the data signify the difference between male $($ mean $=3.65$; std.dev $=0.51)$ and female .undergraduate degree holders(mean $=3.46$; std.dev $=0.45)$, in which male undergraduate degree holders are more motivated than females. Also, there is a significant different motivation between adult learners based on their living situation. The data shown that adult learners who live with others (mean $=3.63$; std.dev $=0.47$ ) have higher motivation than those who live alone (mean $=3.42$; std.dev $=0.56$ ) based on independent $t$-test $(t=-$ 2.222, $p$-value $<0.05)$. In addition, when motivation to learn is compared across age groups of participants, it indicates no significant difference $(F=1.282, p$-value $>0.05)$.
\end{abstract}

Keywords: motivation, gender, age, and living status

\section{Introduction}

Speaking is the active way to express people's thoughts and give oral information to other people. It is similar to the definition of speaking stated by Tarigan $(1985, \mathrm{p} .17) \mathrm{He}$ states that speaking is one of the language skills in oral form to express the speaker's ideas to everybody. He also defined that speaking is the informal interchange of thought and information by spoken words. In other chance, Tarigan (1981, p. 3) also states that "speaking is one of language skill that develop in children's life begin from listening, in the same time where speaking is learnt". This statement proves that speaking is a process that closely related to listening process.

Students might have different experience in learning English. Zehler (1994) suggested that even though ESL students come from different social status, they do have same need similarities. Therefore, they need to master spoken, reading and writing skills in English. ESL 
students might be diverse in their economic backgrounds. Some may come from backgrounds where there have problems with finance or health. Others may simply need understanding about some of the special circumstances they face

One thing that can not be denied when discussing about learning English and its ESL students is motivation. It is widely believed that motivation has a big impact on students' academic achievement. When having high motivation, students will be able to get grades as expected in their studies. Wigfield and Guthrie (1997) stated that students who perceive high motivations will gain a better achievement than those who do not. Kleinginna (1981) said that motivation is influence of needs and desires on doing an activity. While, Geen (1995) defined motivation as the initiation, direction, intensity and persistence of human behavior. So when someone has initiation to something that is called motivation. Based on the previous opinions, the reseacher proposed that motivation is something which is strong that encourages someone to do something based on their initiation and desire.

Marshall (1987) defined motivation as value, and benefits of academic tasks to the learners. Ames (1990) proposed the definition of motivation as process, engagement in learning activities. Also, motivation is something that affect the success of ESL students in the classroom (Masgoret \& Gardner, 2003).

Keller (2002) proposed that students' participation is a good way to improve their interests in learning, which contributes to motivation. ESL students who are able to come out with their goals and evaluate their own progress were confirmed to be more motivated. Since the relationship between integrative motivation and classroom behaviors is unclear, promoting positive classroom might be a good option for teachers to enhace learners' motivation (Cook, 2002).

Oxford and Ehrman (1993) emphasizes on the importance of teachers to fully pay attention on students' learning motivation. It can be done by assuring the materials and the tasks are communicative and appropriate to the learners. In learning foreign Language, motivation advocates learners to achieve a high level of English proficiency (Gardner, 2001). The motivated learner defined by Gardner (2001) is a student who not only gives his best effort to learn English, but also enjoy the process of language learning. Inspite of the controversy about the role that different constructs play in mastering a foreign language, motivation becomes one of the substantial aspects that controls the different stages of foreign language learning (Taha, 2007).

Some theories have formed the educational concept of motivation particularly. These theories cover the theory of integrative motivation introduced by Gardner (2001), the Attribution theory and its implications for task persistence and goal attainment as proposed by Weiner (2000) and the Self Determination Theory with its categories of intrinsic and extrinsic motivation developed by Ryan and Deci (2000).

\section{Integrative vs. Instrumental}

When discussed about the role of motivation and attitudes in English learning, Gardner (2001) introduced instrumental and integrative motivation as the two main modes of motivation. As suggested by Gardner (2001), integrative motivation is usually found when 
students communicate with communities that use the target language as their main language of communication. Dornyei (2003) confirmed that integrative motivation does not only motivate the learners to learn the target language but also encourage the learner to communicate with the target language communities when available.

McIntyre (2002) asserted that integrative motivation always leads to positive attitudes to target language communities, cultures, and countries. Instrumental motivation is apparent when the learners study the language as a means for achieving some goals like applying a job, travelling to a country where the language is spoken, or being able to continue further studies conducted in the target language Gardner (2001).

\section{Attribution Theory}

Referring to the work of McIntyre (2002), Attribution theory is a specific and valuable model to justify how learners' perceptions of the causes of their success or failure. Individuals' attributions may be internal factor from the learner's abilities. They can also be external that might be out of the learner's control (Ryan \& Deci, 2000).

\section{Self- Determination Theory}

Stemming from the field of psychology, Self Determination Theory (SDT) recommeds that intrinsic motivation has three psychological needs: autonomy, competence, and relatedness where autonomy represents learner initiated actions, competence reflects students' mastery of target content, and relatedness shows the learner's need to be accepted and appreciated by others (Ryan et al. 2000). Chirkov et al., (2005) proposed that one of the major emphases of SDT is the central role of self-motivation and student autonomy as providing with great academic achievement and healthy student development across the nation.

Moreover, there are a lot of research conducted by researchers which focus on motivation, such as Daniel and Arapostathis (2005) in their research "What do they want". They found that establishing relationships with teachers, being interested in school assignments, and feeling skilled to perform tasks the ways the teachers want to, create motivating learning environments. There also studies on motivation based on gender. In this regard, Stake (1984) found that male students' motivation is higher than that of women. This finding is also defended by Cavallo, Potter, and Rozman (2004). In their research, they found that male students had significantly higher motivation, performance goals, and physics understanding compared to females, which persist throughout the course.

While studies on motivation in general have been widely discussed by the motivational and educational experts, studies on specific issues around motivation are still limited. For example, how is motivation to learn impacted by challenges and fatigue? Moreover, are males more motivated than females when they are challenged and fatigue? Do age, living status, and education play a role in this matter?

In this paper, the researcher explored motivation to learn English when facing difficulties and fatigue among ESL students while controlling for education (undergraduate and graduate degree holders), gender, age, living status (living alone and living with others). To start with, 
the researcher hypothesized that graduate degree holders have a higher motivation to learn than those of undergraduate degree holders. Subsequently, I explore the difference while controlling for gender, living status, and age.

\section{Method}

This research applied quantitative method in which the data were collected through survey distributed to the students. Forty two males and sixty two females of undergraduate degree holders and thirty five males and fifty nine females of graduate degree holders participated in the study conducted by the researcher. The range of age of the participants in the survey is from 16 to 66 years old, with a mean of 35.18 years and standard deviation of 11.90. Some basic characteristics of the participants are shown in Table 1 and Table 2.

Table 1 Education by Gender

\begin{tabular}{ll|r|r|r}
\hline & & \multicolumn{2}{|c|}{ Gender } & \\
\cline { 3 - 4 } & & Male & Female & Total \\
\hline Education & Undergraduate degree & 42 & 62 & 104 \\
& Graduate degree & 35 & 59 & 94 \\
Total & 77 & 121 & 198 \\
\hline
\end{tabular}

Table 2 Education by Living Situation

\begin{tabular}{ll|r|r|r}
\hline & & \multicolumn{2}{|c|}{ Living_Situation } & \multicolumn{2}{c}{ Total } \\
\cline { 3 - 5 } & \multicolumn{2}{c|}{ Alone } & With others & \multicolumn{2}{c}{104} \\
\hline Education & Undergraduate degree & 25 & 78 & 94 \\
& Graduate degree & 20 & 74 & 198 \\
& & 45 & 152 & \\
\hline
\end{tabular}

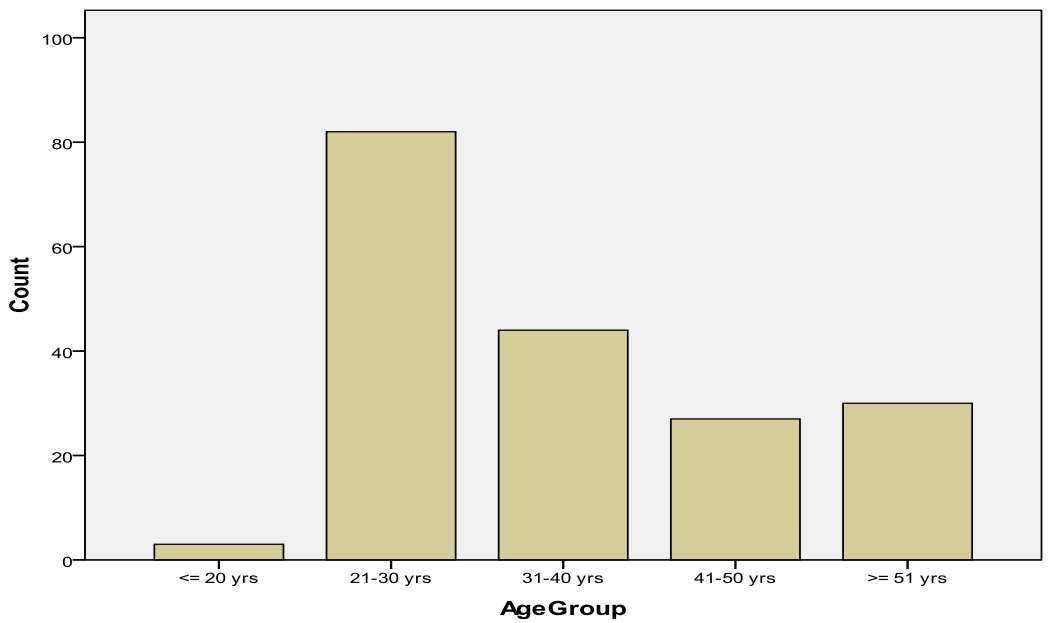

Figure 1 Distribution of age among participants in the survey 
There were seven items in motivation to learn inventory survey They items are: When given with new tasks, I enjoy and like it; I work harder to complete tasks althought I am enhausted; Even when I am tired; I still summit my assignment; I remain excited in a subject presented to me; I often look further information about topics discussed in class; When given a choice by the teacher, I choose harder tasks; I look for new materials to learn. The seven items were related to learning motivation and these items are considered as the most related to motivation to learn English when facing difficulties and fatigue. Graduate and undergraduate degree holders were asked to take the survey voluntarily. The students ranked the frequency of their behavior indicated for each survey items as never, rarely, sometimes, often, and always. The answers were given a score from one for 'never' to five for 'always', and the seven scores were averaged for each individual for a Motivation to Learn English When Facing Difficulties and fatigue score.

\subsection{Participants}

The participants of this research were 198 English Second Language Students (ESL) of the university of Arkansas who pursued their undergraduate and graduate program. They comprised 77 males and 121 females that represented the all ESL students studying at the university.

\subsection{Data Collection}

\subsubsection{Instrument of Collecting Data}

The researcher decided to use questionaire as the instrument of collecting his data. The students were asked to answer questions as stated on the questionaire using the likert scale.

\subsubsection{Techniques for Collecting Data}

For collecting the data, the researcher applied purposive sampling in which the sample was chosen for specific purposes. In this research, the researcher only chose ESL students who were studying at the University of Arkansas.

\subsection{Data Analysis}

The researcher analyzed the data statistically using SPSS software. Some test were carried out such as mean,std deviation, and t-test.

\section{Findings}

The data were converted to $t$ scores and analyzed with independent t-test. Initially, all undergraduate degree holders were compared to all graduate degree holders. Motivation to learn English when facing difficulties and fatigue of undergraduate degree holders (mean = 3.54; std.dev $=0.48$ ) is not significantly different from that of the graduate degree holders (mean $=3.64 ;$ std.dev $=0.52$ ) based on independent t-test, $\mathrm{t}=-1.270, \mathrm{p}$-value $>0.05$. Similarly, controlling for gender, motivation to learn when challenged and despite fatigue between male graduate degree holders $($ mean $=3.60$; std.dev $=0.45$ ) and female graduate 
degree holders $($ mean $=3.62 ; \mathrm{SD}=0.55)$ was not significantly different with $\mathrm{t}=0.585$, and $\mathrm{p}$ value $=0.560$.

However, among under graduate degree holders, motivation to learn when challenged and fatigue (MCLF) is different between male (mean $=3.65$; std.dev $=0.51$ ) and female (mean=3.46; std.dev $=0.45)$, but only at $10 \%$ significant level ( $\mathrm{p}$-value $=0.080)$. Moreover, there is a significant different motivation between adult learners based on their living situation. The data shown that adult learners who live with others (mean=3.63;std.dev $=0.47$ ) have higher motivation than those who live alone (mean $=3.42$; std.dev $=0.56$ ) based on independent $\mathrm{t}$-test $(\mathrm{t}=-2.222$, $\mathrm{p}$-value $<0.05)$. In addition, when motivation to learn is compared across age groups of participants, it indicates no significant difference $(\mathrm{F}=1.282$, p-value $>0.05)$.

\section{Discussion}

This research has proved that there is not significant different between undergraduate and graduate degree holders in term of motivation to learn even when they face difficulties and fatigue. However, when comparing the motivation based on the gender, the data signify the difference between male and female undergraduate degree holders, in which male undergraduate degree holders are more motivated than females.

\section{Conclusions}

The analysis could either support the findings of the difference based on the education level or genders, as indicated in this study. In addition, developing the quantity of survey items would also expand this study. When motivation to learn is observed based on the living situation, it states that adult learners who live with others have higher motivation than those who live alone. Moreover, when motivation is monitored based on the age of participants, it indicates that there is no significant difference across the age.

\section{References}

Brown, H. (2001). Teaching by principle an interactive approach to language pedagogy. San Francisco: Longman.

Ames, C A. 1990. Motivation: What Teachers Need to Know. Teachers College Record, $3,92-97$.

Cavallo, M.L. A., Potter, H.W., \& Rozman, M. 2004. Gender Differences in Learning Constructs, Shifts in Learning Constructs, and Their Relationship to Course Achievement in a Structured Inquiry, Yearlong College Physics Course for Life Science Majors. School Science and Mathematics, 104(6), 288-300. Retrieved March 16, 2009, from Research Library database. (Document ID: 712624961).

Chirkov, V.I., Ryan, R.M. \& Willness, C. 2005. Cultural context and psychological needs in Canada and Brazil: Testing a self-determination approach to internalization of cultural practices, identity and well-being'. Journal of Cross-cultural Psychology, 36,425-433. 
Motivation to Learn English When Facing Difficulties and Fatigue

Among ESL Students of University of Arkansas

Cook, V. 2002. Portraits of the L2 user. Boston: Harvard University.

Daniels, E., \& Arapostathis, M. 2005. What do they really want? Urban Education, 40, 34-59.

Dornyei, Z. 2003. Motivational strategies in the language classroom. Cambridge: CUP.

Gardner,J.2001.Integrative motivation andsecond-language acquisition. Honolulu, $\quad \mathrm{HI}$ : University of Hawai'i Press.

Geen, G. R. 1991. Social motivation. Annual Review of Psychology, 42, 377-399.

Kleinginna, P., Jr., \& Kleinginna A. 1981. A categorized list of motivation definitions, with suggestions for consensual definition. Motivation and Emotion, 5, 263-291.

Keller, J. 2002. Motivational design for learning and performance: The ARCS Model approach. New York, NY: Springer-Verlag.

Marshall, H. H. 1987. Motivational strategies of three fifth-grade teachers. The Elementary School Journal 88, (2). 135-150.

Masgoret, A. M., \& Gardner, R. C. 2003. Attitudes, motivation, and second language learning. Language Learning, 53, 123-163.

McIntyre, P.D. 2002. Motivation, anxiety and emotion in second language acquisition. USA: John Benjamins Publishing Company.

Oxford, R. \& Ehrman, M. 1993. Second language research on individual differences. Annual Reviewof Applied Linguistics, 13,188-205.

Ryan, R.M. \& Deci, E.L. 2000. Self-determination theory and the facilitation of intrinsic motivation, social development, and well-being. American Psychologist, 55, 68 - 78.

Stake, E. J. 1984. Educational and career confidence and motivation among female and male undergraduates. American Educational Research Journal, 21, 565-578

Taha, T. A. 2007. Arabic as a critical need foreign language in Post 911 Era A study of students attitudes and motivation. Journal of Instructional Psychology, 34,, 150-160.

Weiner, B. 2000).Intrapersonal and interpersonal theories of motivation from an attributional perspective. Educational Psychology Review, 12, 1-13.

Wingfield, A., \& Guthrie, T. J. 1997. Relations of children's motivation for reading to the amount and breadth of their reading. Journal of Educational Psychology, 89, 420-432.

Zehler, A. 1994. Working with English language learners: Strategies for elementary and middle school teachers. NCBE Program Information Guide Series, 19,12-18. 